Syntax Literate: Jurnal Ilmiah Indonesia p-ISSN: 2541-0849

e-ISSN : 2548-1398

Vol. 6, No. 10, Oktober 2021

\title{
POLITIK HUKUM HILIRISASI DAN INKUBASI BISNIS HASIL RISET DAN PENELITIAN PENGEMBANGAN PERGURUAN TINGGI NEGERI
}

\section{Muhammad Rizki Noveri, I Putu Eka Cakra, Joko Setiyono}

Program Magister Ilmu Hukum, Fakultas Hukum Universitas Diponegoro (UNDIP), Semarang, Jawa Tengah, Indonesia

Email: muhammadrizkinoveri@students.undip.ac.id, ekacakra11@gmail.com, jokosetiyono61@yahoo.com

\begin{abstract}
Abstrak
Proses hilirisasi dan inkubasi bisnis hasil riset dan penelitian pengembangan oleh Perguruan Tinggi Negeri perlu terus didorong agar dirasakan manfaatnya oleh masyarakat. Kelemahan selama ini terdapatnya gap yang besar antara sisi penelitian dan sisi industri; dari sisi peneliti banyak peneltian yang tidak berlanjut untuk hilirisasi (dimanfaatkan industri) sedangkan disisi industri terdapat keengganan guna memakai hasil riset dan penelitian pengembangan oleh Perguruan Tinggi. Penelitian ini menggunakan metode Yuridis Normatif (legal research), dengan metode pendekatan perundang-undangan, pendekatan konseptual dan pendekatan historis, dilengkapi data-data sekunder yang mencakup bahan hukum primer, bahan hukum sekunder dan bahan hukum tertier, yang diperoleh melalui studi dokumen atau bahan pustaka, yang nantinya berusaha menggambarkan (mendeskripsikan) tentang rumusan masalah yakni: politik hukum hilirisasi dan inkubasi bisnis hasil riset dan penelitian pengembangan oleh Perguruan Tinggi guna meningkatkan daya saing dan kemandirian bangsa dan alih teknologi, serta pentingnya penerapan konsep ideal sinegritas elemen (harmonisasi) Quadrulupe Helix guna mempelancar kegiatan hilirisasi dan inkubasi bisnis hasil riset dan penelitian pengembangan oleh Perguruan Tinggi.
\end{abstract}

Kata Kunci: polituk hukum; daya saing bangsa; inkubasi bisnis; riset; penelitian; pengembangan

\section{Abstract}

research by State Universities needs to be continuously encouraged so that the benefits will be felt by the community. The weaknesses so far are the large gap between the research side and the industry side; from the research side, many researches do not continue for downstreaming (utilized by industry) while on the industrial side there is a reluctance to use the results of research and development research by higher education institutions. This research uses the juridical normative method (legal research), with the statutory approach method, conceptual approach and historical approach, supplemented by secondary data which includes primary legal material, secondary le gal material and tertiary legal material, which is obtained through document or material study. literature, which later tries to describe (describe) the formulation of the problem, namely: downstream legal politics and business incubation of research and development research results by

$\begin{array}{ll}\text { How to cite: } & \text { Noveri. M. R., Cakra, I P, E, \& Setiyono, J. (2021) Politik Hukum Hilirisasi dan Inkubasi Bisnis Hasil } \\ & \text { Riset dan Penelitian Pengembangan Perguruan Tinggi Negeri. Syntax Literate: Jurnal Ilmiah Indonesia, } \\ & 6(10) . \text { http://dx.doi.org/10.36418/ Syntax-Literate.v6i10.4366 } \\ \text { E-ISSN: } & \text { 2548-1398 } \\ \text { Published by: } & \text { Ridwan Institute }\end{array}$


Higher Education in order to increase the competitiveness and independence of the nation and technology tranfer, as well as the importance of implementing the ideal concept of elemental integrity (harmonization) of Quadrulupe Helix for smoothing downstream activities and business incubation of research and development research results by Higher Education.

Keywords: politics of law; nation's competitiveness; business incubation; research; research; development

Received: 2021-09-20; Accepted: 2021-10-05; Published: 2021-10-20

\section{Pendahuluan}

Indonesia telah menegaskan sebagai negara hukum, hal ini dimuat dalam Pasal 1 ayat (3) Undang Undang Dasar (UUD) 1945 hasil amandemen ke-3 menyatakan: "Negara Indone sia adalah negara hukum".(Sekretariat Jenderal MPR, n.d.) Hamdan Zoelva berpendapat: "Konsep negara hukum Indonesia bisa digali dari Pembukaan UUD 1945 yang memuat pernyataan kehendak dan cita lahirnya Indonesia merdeka, bersatu, adil dan berdaulat, serta rumusan falsafah negara yang terkandung dalam pembukaan itu.'(Zoelva, 2015)

Salah satu ciri negara hukum adalah adanya jaminan yang kuat terhadap hak-hak asasi manusia (HAM) tanpa diskriminatif. Frederich Julius Stahl dalam karyanya Philosophie des Recht (1878), mengungkapkan paham negara hukum formal mengandung unsur-unsur antara lain (Rani, 2011): 1). Mengakui dan melindungi HAM 2). Untuk melindungi HAM tersebut maka penyelenggaraan negara berdasarkan atas teori trias politica 3). Pemerintah dalam menjalankan tugasnya harus berdasarkan undang-undang (wetma tig bestuur) 4). Terdapatnya peradilan administrasi guna menyelesaikan pelanggaran hak asasi (campur tangan pemerintah dalam kehidu pan pribadi) oleh Pemerintah.

Jaminan yang kuat terhadap HAM tanpa diskriminatif merupakan satu ciri negara hukum ini dipertegas kembali berdasarkan rumusan pertemuan International Congress of Jurist di Athena Tahun 1955 dan di Bangkok Tahun 1965 (Muabezi, 2017).

Pasal 28 C ayat (1), UUD 1945 hasil amandemen ke-2 mengatur HAM, dimana "Setiap orang berhak untuk mengembangkan diri melalui pemenuhan kebutuhan dasarnya, berhak mendapat pendidikan dan memperoleh manfaat dari ilmu pengetahuan dan tekhnologi, seni dan budaya, demi meningkatkan kualitas hidupnya dan demi kesejahteraan umat manu sia." dan Pasal 28 C ayat (2) menyatakan: "Setiap orang berhak untuk memajukan dirinya dalam memperjuankan haknya secara kolektif untuk membangun masyarakat, bangsa dan negara."

Undang-Undang Nomor 17 Tahun 2007 tentang Rencana Pembangunan Jangka Panjang Nasional (UU-RPJPN) Tahun 2005-2025 sebagaimana diturunkan melalui Peraturan Presiden Nomor 18 Tahun 2020 tentang Rencana Pembangunan Jangka Menengah Nasional (Perpres-RPJMN) Tahun 2020-2024, terdapat 4 (empat) pilar utama RPJMN yang diturunkan menjadi 7 (tujuh) Agenda Pemba ngunan RPJMN, dimana agenda ke-3 (tiga) nya yaitu: "Meningkatkan Sumber Daya Manusia Berkualitas 
dan Berdaya Saing".(Peraturan Presiden No 18 Tahun 2020 Tentang Rencana Pembangunan Jangka Menengah Nasional Tahun 2020-2024, n.d.)

Hal ini selaras dengan Nawacita pada Kabinet Presiden Joko Widodo Periode I (program ke-6) mengamanatkan perlunya meningkatkan produktivitas rakyat dan daya saing di pasar Internasional (Asnawi, 2018). Pada periode ke-2 kepemimpinannya, cita tersebut ditegaskan lagi sebagai salah satu dari 5 (lima) program prioritas yakni; "transformasi pembangunan ekonomi berbasis inovasi untuk penguatan dan peningkatan daya saing bangsa."(Anggota Dewan Riset Nasional, 2020).

Tabel 1

Rangking Daya Saing

Rangking Daya Saing

\begin{tabular}{|c|c|c|c|c|c|c|c|c|c|c|}
\hline & \multicolumn{2}{|c|}{ Singapura } & \multicolumn{2}{|c|}{ Malaysia } & \multicolumn{2}{|c|}{ Thailand } & \multicolumn{2}{|c|}{ Indonesia } & \multicolumn{2}{|c|}{ Philipina } \\
\hline & 2020 & 2019 & 2020 & 2019 & 2020 & 2019 & 2020 & 2019 & 2020 & 2019 \\
\hline $\begin{array}{l}\text { Overall } \\
\text { Performance }\end{array}$ & 2 & 2 & 26 & 26 & 39 & 40 & 56 & 56 & 57 & 55 \\
\hline $\begin{array}{l}\text { Factor I. } \\
\text { Knowledge }\end{array}$ & 2 & 3 & 19 & 19 & 43 & 43 & 63 & 56 & 62 & 51 \\
\hline $\begin{array}{l}\text { Sub Factor } \\
\text { Rangking }\end{array}$ & & & & & & & & & & \\
\hline 1.Talent & 1 & 1 & 30 & 22 & 36 & 40 & 43 & 42 & 55 & 41 \\
\hline $\begin{array}{l}\text { 2.Training \& } \\
\text { Education }\end{array}$ & 7 & 4 & 8 & 11 & 55 & 50 & 63 & 61 & 59 & 54 \\
\hline 3.Scientific & 10 & 22 & 27 & 26 & 37 & 35 & 51 & 52 & 56 & 54 \\
\hline $\begin{array}{l}\text { Factor II. } \\
\text { Technology }\end{array}$ & 1 & 1 & 20 & 19 & 22 & 27 & 54 & 47 & 53 & 55 \\
\hline $\begin{array}{l}\text { Sub Factor } \\
\text { Rangking }\end{array}$ & & & & & & & & & & \\
\hline $\begin{array}{l}\text { 1.Regulatory } \\
\text { Framework }\end{array}$ & 1 & 2 & 35 & 29 & 31 & 33 & 51 & 51 & 62 & 60 \\
\hline 2.Capital & 11 & 8 & 18 & 14 & 17 & 21 & 41 & 26 & 39 & 40 \\
\hline 3.Technology & 1 & 1 & 15 & 20 & 25 & 29 & 55 & 56 & 49 & 51 \\
\hline $\begin{array}{l}\text { Factor III. } \\
\text { Future } \\
\text { Readiness }\end{array}$ & 12 & 11 & 32 & 28 & 45 & 50 & 48 & 58 & 54 & 54 \\
\hline $\begin{array}{l}\text { Sub Factor } \\
\text { Rangking }\end{array}$ & & & & & & & & & & \\
\hline $\begin{array}{l}\text { 1.Adaptive } \\
\text { Attitudes }\end{array}$ & 20 & 19 & 30 & 30 & 53 & 58 & 58 & 60 & 57 & 53 \\
\hline $\begin{array}{l}\text { 2.Business } \\
\text { Agility }\end{array}$ & 11 & 6 & 30 & 17 & 44 & 30 & 24 & 21 & 32 & 42 \\
\hline $\begin{array}{l}\text { 3.IT } \\
\text { Integration }\end{array}$ & 3 & 4 & 33 & 33 & 43 & 51 & 60 & 60 & 56 & 58 \\
\hline
\end{tabular}

Dewasa ini tingkat kemakmuran suatu bangsa sangat tergantung daya saing dimilikinya, dan selanjutnya daya saing bangsa itu tergantung pada perkembangan teknologi yang mereka kuasai. Hal ini tidak terlepas dari dampak globalisasi yang telah mempengaruhi segala sendi kehidupan masyarakat (Soebagyo, 2018). 
International Intitute for Management Development (IMD) telah merilis World Digital Competitiveness Rangking (WDCR) Tahun 2020. Peringkat daya saing Indonesia menga lami penurunan 8 (delapan) peringkat dari posisi 32 menjadi 40. Bila dibandingkan dengan negara ASEAN posisi Indonesia berada dibawah Singapura, Malaysia dan Thailand dan diatas Filipina, sedangkan untuk level Asia Pasifik posisi Indonesia berada di peringkat 11 dari 14 negara diatas India dan Filipina (Asmara, 2020)

Posisi Indonesia berdasarkan data IMD World Digital Competitiveness Rangking Tahun 2020 berada dalam kelompok 10 terbawah, yakni tetap berada di peringkat 56 meski di faktor kesiapan masa mendatang membaik, terutama dalam e-partisipasi (ke-58 hingga ke-45) dan ritel internet (ke-58 hingga ke-50). Peningkatan seperti itu diimbangi dengan penurunan faktor teknologi di mana efisiensi layanan perbankan dan keuangan, tingkat investasi di bidang teleko munikasi dan broadband nirkabel (tingkat pene trasi, per 100 orang) menunjukkan penurunan yang tajam. Berdasarkan Tabel. 1 (diatas) dapat kita lihat posisi daya saing Indonesia dari tahun 2019 - 2020 berdasarkan 3 (tiga) faktor penilaian mengalami penurunan:

1. Faktor ilmu pengetahuan (knowledge); yaitu sub-faktor bakat (talent), dan sub-faktor pendidikan/pelatihan (training education),

2. Faktor teknologi yaitu sub-faktor modal (capital) dan

3. Faktor kesiapan menghadapi masa depan yaitu sub-faktor business agility

Dewan Riset Nasional mencatat "Untuk menghasilkan produk hilir dalam rangka menciptakan nilai tambah dan kemampuan bersaing, cara yang paling ampuh adalah menguasai ilmu pengetahuan dan teknologi (iptek) serta menerapkannya di dunia industri. Penguasaan iptek melalui lembaga penelitian dan pengembangan perguruan tinggi, kementerian, serta lembaga non kementerian serta swasta dalam bentuk invensi ternyata tidak begitu mudah dihilirisasi menjadi produk yang di komersialisasi."

Tugas pendidikan tinggi (PT) adalah untuk mengimplementasikan Tridharma yaitu: "pendidikan, penelitian dan pengabdian masya rakat." Pasal 4 Undang-Undang Nomor 12 Tahun 2012 tentang Pendidikan Tinggi (UU-Dikti) menyebutkan; Pendidikan Tinggi berfungsi:

a. Mengembangkan kemampuan dan memben tuk watak serta peradaban bangsa yang bermartabat dalam rangka mencerdaskan kehidupan bangsa

b. Mengembangkan sivitas akademika yang inovatif, responsif, kreatif, terampil, berdaya saing, dan kooperatif melalui pelaksanaan Tridharma

c. Mengembangkan Ilmu Pengetahuan dan Teknologi dengan memperhatikan dan menerapkan nilai Humaniora

Banyak penelitian yang telah dilakukan oleh berbagai Perguruan Tinggi (universitas), tetapi hasil penelitian mereka belum banyak dirasakan oleh masyarakat. Sudah menjadi rahasia umum banyak penelitian yang dibuat hanya disimpan atau dinikmati kalangan tertentu, padahal seyog yanya penelitian tersebut bisa manghasilkan manfaat/digunakan masyarakat. 
Sudah menjadi rahasia umum selama ini terdapat gap (celah/kesenjangan), "mismatch" antara Perguruan Tingi (akademisi) dalam hal ini sebagai pihak yang melakukan penelitian dan pengembangan (innovation) dengan industri (dunia bisnis) sebagai pihak yang nantinya menggunakan hasil keluaran riset, penelitian dan pengembangan Perguruan Tinggi. Sebagai akibatnya Industri tidak mengetahui riset, penelitian pengembangan apasaja yang telah dilaksanakan oleh Perguruan Tinggi dan sebaliknya Perguruan Tinggi tidak mengetahui apa yang dibutuhkan oleh Industri.

Berdasarkan hal-hal sebagaimana diutarakan pada latar belakang masalah diatas, penulis tertarik untuk meneliti "Politik Hukum Hilirisasi dan Inkubasi Bisnis Hasil Riset dan Penelitian Pengembangan Perguruan Tinggi”.

\section{Metode Penelitian}

Berdasarkan perumusan masalah dan tujuan penelitian maka metode penelitian yang dipergunakan dalam penelitian ini adalah metode penelitian yang bersifat yuridis normatif (legal research). Dalam melakukan penelitian hukum normatif ini, penulis menggunakan metode pende katan yaitu: 1). Pendekatan perundang-undangan (statute approach): dilakukan dengan mene laah semua undang-undang dan regulasi yang bersangkut paut dengan isu hukum yang sedang ditangani (diteliti). 2). Pendekatan konseptual (conceptual approach): dilakukan dengan cara meng gunakan doktrindoktrin dalam ilmu hukum dan pandangan para pakar/ahli hukum. 3). Pendekatan Historis (Historical Approach). Data diperoleh melalui studi dokumen atau bahan pustaka (documentary study), yaitu suatu teknik pengumpulan data dengan mencari landasan teoritis dari permasalahan penelitian dengan mempelajari kepustakaan/ literatur-literatur, dokumen-dokumen dan data yang ada berkaitan dengan masalah yang akan diteliti "Hilirisasi dan inkubasi bisnis hasil riset dan penelitian pengembangan oleh Perguruan Tinggi”. Pengelolaan data dilakukan sejak peneliti mendapat data dari literasi dengan membuat fieldnote. indexing, grouping, dan filtering. Berdasarkan jenis penelitian penulisan ini "yuridis normatif", dengan pendekatan dekriptif maka data yang dikumpulkan adalah data kualitatif: yaitu dilakukan dengan cara menarik kesimpulan deduktif-induktif

\section{Hasil dan Pembahasan}

Berikut ini diuraikan mengenai beberapa teori-teori pokok yang digunakan dalam menganalisa 2 (dua) rumusan permasalahan yang diajukan dalam penulisan penelitian ini. 


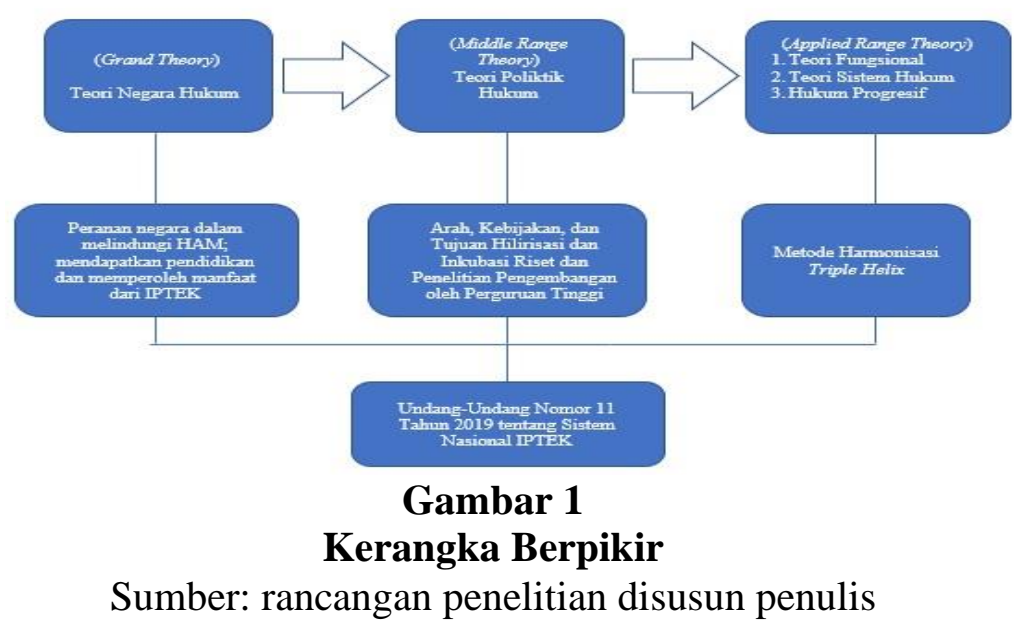

Teori tersebut dapat dibagi menjadi tiga tataran yaitu:

1. Teori Makro (Grand Theory)

2. Teori Meso (Middle Range Theory)

3. Teori Mikto (Applied Range Theory)

Grand Theory yang akan digunakan dalam penelitian ini adalah Teori Negara Hukum. Middle Range Theory yang digunakan dalam Tesis ini adalah Teori Politik Hukum, Adapun Applied Range Theory yang digunakan dalam Tesis ini adalah Teori Sistem Hukum, Teori Struktural Fungsional (Teori Sibernetika), dan Teori Hukum Progresif

Penulis dalam menganalisa rumusan masalah penelitian ini cenderung sependapat dengan pengertian politik hukum yang dikemukakan (diberikan) oleh Satjipto Rahardjo dan Moh. Mahfud M.D, kemudian penulis mencari titik singgung anasir-nya dengan menggunakan teori sistem hukum Lawrence Friedman dan Teori Struktur Fungsional (Sibernatika) Talcot Parson, dan guna menghindari terjebak dalam positivism hukum penulis menggunakan Teori Hukum Progresif Satjipro Rahardjo

1. Teori Negara Hukum

Konsep negara hukum adalah konsep yang universal dan merupakan produk sejarah, dimana pada implementasi terdapat prinsip. model dan kharateristik beragam karena faktor situasi dan kesejahteraan. Pada negara "Eropa Kontinental" dinamakan rechstaat, dinegara-negara "Anglo Saxon" dinamakan rule of law, dinegara "Sosialis", dinamakan socialist legality, Negara Hukum Islam (Nomokrasi Islam) dan di Indonesia dinamakan negara hukum Pancasila (Patamatta, 2020)

Pada abad ke-18 paham rechstaat berkembang di negara-negara Eropa Kontinental dipelopori oleh; Immanuel Kant (1724-1804), Friederich Julius Stahl, Paul Laband dan Fitche. Imanuel Kant memberikan idenya terhadap negara hukum dalam karya ilmiahnya berjudul Methaphysiche Ansfangs grunde der Rechtslehre (azas-azas metafysis dari ilmu hukum) sering disebut negara hukum liberal (negara penjaga malam).(Rani, 2011) Friderich Julius Stahl (1802-1861) seorang sarjana hukum asal Jerman, mengemukakan konsep guna memperbaiki kelemahan konsep negara hukum liberal/ negara penjaga malam dari Immanuel Kant dimana dikenal 
dengan konsep negara hukum formal. Kriteria negara hukum oleh Immanuel Kant hanya terbagi 2 (dua) kelompok yaitu: (a). adanya perlindungan terhadap hak asasi manusia, (b). adayan pemisahan kekuasaan. Sthal berpendapat 2 (dua) kriteria negara tersebut hanya bertindak memisahkan apabila terjadi perselisihan antar sesame warga negara tidak mengatur apabila melibatkan negara, disini negara hanya berpungsi sebagai "penjaga malam" (Nachtwachter Staat). Berdasarkan pemikiran tadi Stahl menambahkan 2 (dua) unsur pokok negara hukum Immanuel Kant tadi dengan: (c). Setiap tidakan pemerintah harus berdasarkan undang-undang yang dibuat terlebih dahulu (d) Terdapatnya peradilan administrasi yang bertugas menyelesaiakan perselisihan penguasa dengan Masyarakat (Rusnan, 2014).

Dinegara-negara Anglo Saxon dikenal dengan konsep negara hukum yang disebut "rule of law" atau pemerintah oleh hukum dengan tokoh nya Albert Venn Dicey (A.V. Dicey). Berbeda dengan konsep negara hukum Eropa Kontinental maka dalam rule of law menurut Anglo Saxon tidak dikenal unsur peradilan administrasi, karena menurut konsep rule of law setiap peroalan hukum diselesaikan dalam peradilan sama. A.V Dicey mengatakan ada 3 (tiga) unsur penting/ciri setiap negara hukum yaitu: (Wijaya, 2013)

a. Supremacy of Law: mengandung pengertian negara diatur oleh hukum dan seorang individu baru dihukum jika melanggar Hukum. atau dengan kata lain terdapat dominasi dari aturan-aturan hukum untuk menentang atau meniadakan kesewenang-wenang dari pemerintah.

b. Equality Before Law: artinya terdapat persamaan dihadapan hukum untuk semua golongan, tidak ada lagi orang yang berada diatas hukum. atau dengan kata lain semua warga negara baik rakyat maupun pejabat taat pada hukum yang sama (ordinary court) dan jika melanggar hukum diadili di pengadilan yang sama

c. Contitution based on Individual Right artinya secara sederhana yaitu terjaminnya hak-hak asasi manusia oleh undang-undang (konstitusi) serta melaui putusan pengadilan

2. Teori Politik Hukum

Politik hukum secara etimologis (asal usul kata), berasal dari istilah "rechtspolitiek" bahasa Belanda, yang terdiri 2 (dua) kosa kata "recht" yang berarti hukum dan "politiek" yang berarti kebijakan (policy) Di Inggris politik hukum dikenal dengan banyak (beberapa) istilah yakni: "legal policy" yang berarti kebijakan hukum, "politic of law" yang berarti politik hukum, "politic of legal product" yang berarti politik yang tercermin pada produk-produk hukum, "politik of legislation" yang berarti politik perundang-undangan, dan "politic and law development" yang berarti politik pembangunan hukum. Candra Irawan, Politik Hukum Hak Kekayaan Intelektual Indonesia-Kritik Terhadap WTO/Trips Agreement Dan Uapaya Membangun Hukum Kekayaan Intelektual Demi Kepentingan Nasional, Cetakan Ke.1 (Bandung: CV. Mandar Maju, 2012).

Politik hukum sangatlah rumit didefinisikan guna memperoleh pengertian yang utuh tentang apa yang akan dirumuskan, sudah banyak pengertian dan definisi politik 
hukum yang diberikan oleh para ahli hukum dalam berbagai literatur dengan berbagai macam perspektif: (Kalalo, 2018)

a. Perspektif positivisme hukum: definisi politik hukum dapat kita temukan dalam pendapat: L.J Van Apeldoorn yang menggunakan istilah politik perundangundangan (legislation) yaitu "Bagian hukum yang sengaja dibentuk oleh institusi negara, dan apa yang melatar belakangi pembentukan dan pember lakuan suatu peraturan perundang-undangan itulah yang disebut dengan politik hukum”.

b. Perspektif sosiologi: definisi politik hukum dapat kita temukan dalam pendapat Satjipto Rahardjo yaitu: "Aktivitas memilih (hukum hendaknya menyesuaikan dengan tujuan yang hendak dicapai), dan menetapkan mekanisme (cara-cara yang digunakan) dalam rangka mencapai tujuan sosial dan hukum tertentu dalam masyarakat." Terdapat 4 (empat) pertanyaan menda sar yang sering muncul dalam studi politik hukum yakni: (a). tujuan apa yang hendak dicapai dengan sistem hukum yang ada, (b) apakah cara paling tepat (cocok) dalam mencapai tujuan, (c). bagaimana cara hukum dirubah dan kapan seharusnya (waktu) hukum itu tepat dirubah (d). apakah dapat dirumuskan suatu pola yang mapan dan baku yang membantu dalam proses pemilihan tujuan serta cara-cara mencapai tujuan tersebut secara baik.

c. Perspektif kristalisasi dari kehendak-kehendak politik yang saling bersaingan dalam pemberlakuan hukum: definisi politik hukum dapat ditemui dalam pendapat Padmo Wahyono yaitu: "Kebijakan dasar penyelenggara negara yang menentukan arah, bentuk, maupun isi dari hukum yang akan dibentuk dan kriteria untuk menghukumkan sesuatu."

d. Secara harfiah (arti leksikal) pengertian politik hukum dapat ditemukan dalam pendapat Abdul Hakim Garuda Nusantara: politik hukum diartikan sebagai kebijakan hukum (legal policy) yang hendak diterapkan secara nasional oleh suatu pemerintahan negara tertentu, yang meliputi; (a). penerapan hukum positif secara konsisten, (b). pembangunan hukum dan pembaharuan hukum positif yang dianggap telah ketinggalan zaman atau menciptakan hukum baru sesuai dengan perkem bangan yang terjadi dalam masyarakat, (c). penegasan fungsi dan kewenangan lembaga penegak hukum dan (d). pening katan kesadaran hukum masyarakat.

e. Perspektif operasional pengertian politik hukum dapat ditemui dalam pendapat Moh. Mahfud M.D: adalah "Kebijaksaan hukum (legal policy) yang hendak atau telah dilaksanakan secara nasional oleh pemerintah Indonesia, yang implemen tasinya meliputi; Pertama, pembangunan hukum berintikan pembaharuan hukum (pembuatan hukum) terhadapa bahan-bahan hukum yang dianggap asing atau tidak sesuai dengan kebutuhan penciptaan hukum yang diperlukan, Kedua, pelaksanaan ketentuan hukum yang telah ada termasuk penegasan fungsi lembaga dan pembinaan para anggota penegak hukum

3. Teori Fungsional

Teori Fungsional secara terminologi (asal kata) dalam bahasa Inggris disebut 
dengan functional theory, bahasa Belanda disebut funtionele theorie, sedangkan dalam bahasa Jermannya yaitu funktionale theorie, merupakan salah satu teori yang meng analisis (mengakaji) persoalan-persolan yang timbul dalam kemasyarakat berkaitan dengan fungsinya atau keman faatan atau kegunaannya. Secara grama tikal, fungsi disamakan dengan kegunaan suatu hal, sedangkan fungsional sendiri dilihat dari aspek fungsinya.(H.S, 2015)

Pengertian tentang fungsi juga dapat dikaji dan dianalisis dari pendapat yang dikemukakan oleh para ahli/ pakar diantara lain; Talcott Parson mengartikan fungsi sebagai berikut; "Kumpulan kegiatan yang ditujukan kearah pemenuhan kebutuhan tertentu atau kebutuhan sistem". K. Merton memberikan definisi tentang fungsi, Fungsi adalah "Konsekuensi-konsekuensi yang dapat diamati yang menimbulkan adapatasi atau penyesuaian dari sistem tertentu". Kedua ahli tersebut diatas menyajikan konsep tentang fungsi dalam kehidupan masyarakat.

4. Teori Sistem Hukum

Teori Sistem Hukum Menurut Lawrence Friedman: "Unsur-unsur sistem hukum itu terdiri dari struktur hukum (legal struktur), substansi hukum (legal substance) dan budaya hukum (legal culture) (Suteki, 2018). Unsur-unsur tersebut satu sama lain memiliki hubungan saling mempengaruhi. Substansi hukum adalah norma (aturan) hasil dari produk hukum, struktur hukum diciptakan oleh sistem hukum yang mungkin memberikan pelayanan dan penegakan hukum, budaya hukum adalah perilaku, pendapat dan nilai-nilai yang berkaitan dengan hukum (positif/negative).

5. Teori Hukum Progresif

Teori hukum progresif ini dikemukakan oleh Prof. Satjipto Rahardjo yang terkenal dengan filosofi hukumnya: "Hukum itu untuk manusia dan bukan manusia untuk hukum". Hukum bertugas melayani masyarakat bukan sebaliknya, dan kualitas hukum ditentukan dengan kemampuannya untuk mengabdi pada kesejahteraan manusia (Suteki, 2015).

Satjipto Rahardjo dengan pemikirannya yang holistik terhadap hukum menuntunya berpikir melampaui positivisme terhadap hukum, salah satu caranya dengan memasukan ranah ilmu hukum keranah ilmu-ilmu sosial lainnya. Hal ini termasuk langkah progresif karena hal ini memungkinkan hukum itu dianalisa dan dipahami lebih luas.

Munculnya gagasan hukum progresif disebabkan keprihatinan terhadap kondisi (keadaan) hukum di Indonesia dimana rakyat lemah saat berhadapan dengan hukum dan adanya kecendrungan orang yang kuat lolos dari hukum (Rahardjo, 2009).

\section{A. Politik Hukum Hilirisasi Dan Inkubasi Bisnis Hasil Riset Dan Penelitian Pengembangan Perguruan Tinggi}

Landasan Ideal berpikir Indonesia menjadi bangsa yang mandiri dan mempunyai daya saing merupakan amanat dari Pasal 28C ayat (1) dan ayat (2) Undang-Undang Dasar 1945 yang diejawantakan dalam berbagai peraturan perundang-undangan di Indonesia. Hal ini dipertegas kembali dalam Undang- 
Undang yang mengatur Rencana Pembangunan Jangka Panjang Nasional (RPJPN) Undang-Undang Nomor 17 Tahun 2007 dan turunannya Perpres Nomor 18 Tahun 2020 dengan program "Meningkatkan Sumber Daya Manusia (SDM) yang berkualitas dan berdaya saing".

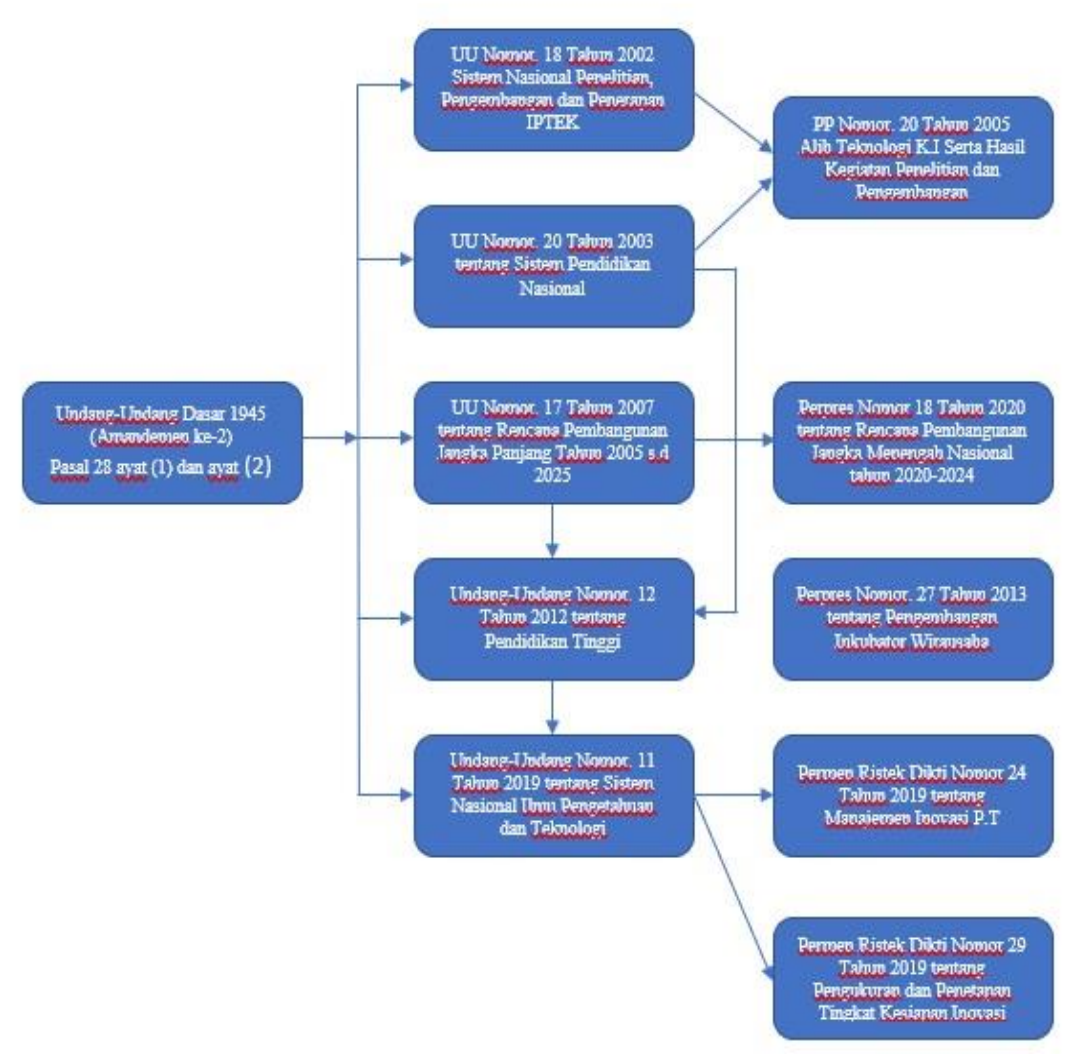

\section{Gambar 2}

Politik Hukum Hilirisasi Riset dan Penelitian Pengembangan Perguruan Tinggi dalam sebaran Perundang-Undangan

Sumber: Dirangkum penulis dari berbagai peraturan perundang-undangan

Beberapa peejawantakan Pasal 28 C ayat (1), dan ayat (2) UUD 1945:

1. Undang-Undang Nomor. 12 Tahun 2012 tentang Perguruan Tinggi (UU-PT). Politik hukumnya terdapat dalam:

a. Pasal 45 ayat (1) UU-PT: "Peneltian di Perguruan Tinggi diarahkan untuk mengembangkan Ilmu Pengetahuan dan Teknologi, serta meningkatkan kesejahteraan masyarakat dan daya saing bangsa".

b. Pasal 46 ayat (1) UU-PT: Hasil penelitian bermanfaat untuk: (a). pengayaan Ilmu Pengetahuan dan Teknologi serta pembelajaran (b). peningkatan mutu Perguruan Tinggi dan kemajuan peradaban bangsa (c). peningkatan kemandirian, kemajuan, dan daya saing bangsa (d). pemenuhan kebutuhan strategis pembangunan nasional (e). perubahan masyarakat Indonesia menjadi masyarakat berbasis pengetahuan. 
2. Undang-Undang Nomor. 11 Tahun 2019 tentang Sistem Nasional Ilmu Pengetahuan dan Teknologi (UU-Sisnas Iptek). Politik hukumnya terdapat dalam:

a. Pasal 14 ayat (1) UU-Sisnas Iptek: "Penyelenggaraan Ilmu Pengetahuan dan Teknologi dilakukan melalui: (a). Pendidikan (b). Penelitian (c). Pengem bangan (d). Pengkajian (e). Penerapan".

b. Pasal 14 ayat (2) UU-Sisnas Ipetek: "Penyelenggaraan Ilmu Pengetahuan dan Teknologi sebagaimana dimaksud pada ayat (1) dikoordinasikan oleh Pemerintah Pusat"

c. Pasal 15 UU-Sisnas Iptek: "Penye lenggaraan Ilmu Pengetahuan dan Teknologi melalui Pendidikan sebagai mana dimaksud Pasal 14 ayat (1) huruf a dilaksanakan dengan: (a). penyiapan sumber daya manusia untuk penye lenggaraan ilmu pengetahuan dan teknogi (b). peningkatan mutu dan kesesuaian ilmu pengetahuan dan tek nologi (c) pengabdian kepada masya rakat sebagai wujud penerapan ilmu pengetahuan dan teknologi

d. Pasal 16 UU-Sisnas Iptek: "Penye lenggaraan Ilmu Pengetahuan dan Tek nologi melalui Pendidikan sebagaimana dimaksud Pasal 15 dilaksanakan dalam rangka meningkatkan kapasitas bangsa dalam mengelola sumber daya dan diutamakan meningkatkan daya saing serta mewujudkan kemandirian bangsa".

e. Pasal 23 ayat (1) UU-Sisnas Iptek: "Pengkajian sebagaimana dimaksud Pasal 14 ayat (1) huruf d ditujukan untuk memastikan manfaat ilmu pengetahuan dan teknologi dalam menyelesaikan permasalahan pembangunan".

f. Pasal 23 ayat (2) UU-Sisnas Iptek: "Pengkajian sebagaimana dimaksud pada ayat (1) dilakukan melalui: (a). Perekayasaan (b) Kliring teknologi (c) Audit teknologi"”.

g. Pasal 27 ayat (1) UU-Sisnas Iptek: "Penerapan sebagaimana dimaksud Pasal 14 ayat (1) huruf e wajib dilaksanakan dengan berbasis pada hasil penelitian, pengembangan dan/atau pengkajian".

h. Pasal 27 ayat (2) UU-Sisnas Iptek: "Penerapan sengaimana dimaksud pada ayat (1) dilaksanakan untuk mendorong Inovasi sebagai upaya peningkatan produktivitas pembangunan, kemandiri an, dan daya saing bangsa".

i. Pasal 28 UU-Sisnas Iptek: "Penerapan sebagaimana dimaksud Pasal 27 dapat dilakukan melalui; (a). Alih Teknologi (b). Intermediasi Teknologi (c) Difusi Ilmu Pengetahuan dan Teknologi (d). Komersialisasi Teknologi”.

j. Pasal 30 UU-Sisnas Iptek: "Intermediasi Teknologi sebagaimana dimaksud Pasal 28 huruf b merupakan upaya untuk menjembatani proses terjadinya Invensi dan Inovasi antara penghasil dan calon pengguna Teknologi

k. Pasal 31 ayat (1) UU-Sisnas Iptek: "Intermediasi Teknologi sebagaimana dimaksud dalam Pasal 30 dapat dilakukan dengan: (a) mendorong implementasi hasil invensi dari lembaga penghasil Teknologi kepada calon pengguna (b). mengidentifikasi kebu tuhan calon pengguna terhadap Tekno logi dibutuhkan". 
1. Pasal 31 ayat (2) UU-Sisnas Iptek: "Intermediasi Teknologi sebagaiman dimaksud pada ayat (1) dapat berupa; (a). inkubasi teknologi (b). temu bisnis teknologi (c). kemitraan (d). promosi hasil invensi

m. Pasal 33 ayat (1) UU-Sisnas Iptek: "Komersialisasi Teknologi sebgaimana dimaksud Pasal 28 huruf d dapat dilakukan melalui: (a). inkubasi teknologi (b). kemitraan industri (c). pengem bangan Kawasan ilmu pengetahuan dan teknologi

n. Pasal 33 ayat (2) UU-Sisnas Iptek: "Pemerintah Pusat dan Pemerintah Daerah besinergi dalam memfasilitasi pengembangan inkubasi teknologi, kemitraan industri, dan/atau pengembangan kawaan ilmu pengetahuan dan teknologi sesuai dengan kesiapan dan keunggulan daerah

o. Pasal 34 ayat (1) UU-Sisnas Iptek: "Pemerintah Pusat dan Pemerintah Daerah wajib mengembangkan Invensi dan Inovasi".

p. Pasal 34 ayat (2) UU-Sisnas Iptek: "Invensi dan Inovasi sebagaimana dimaksud pada ayat (1) ditujuakn untuk: (a). menjadi solusi permasalahan nasional (b). memadukan sudut pandang dan/atau konteks teknis, fungsional, binis, sosial budaya dan estetika (c). menghasilkan nilai tambah dari produk dan/atau proses produksi bagi kesejahteraan masyarakat".

q. Pasal 34 ayat (3) UU-Sisnas Iptek: "Invensi dan Inovasi sebagaimana dimaksud pada ayat (1) dihasilkan dari: (a). Penelitian dasar, penelitian terapan, dan pengembangan (b). Alih Teknologi (c). Rekayasa balik (d). Intermediasi Teknologi (e). Difusi ilmu pengetahuan dan teknologi (f). komersialisasi teknologi”.

r. Pasal 34 ayat (4) UU-Sisnas Iptek: "Ketentuan mengenai Invensi dan Inovasi diatur dengan Peraturan Pemerintah".

s. Pasal 35 ayat (1) UU-Sisnas Iptek: "Pemerintah Pusat wajib memfasilitasi perlindungan Kekayaan Intelektual dan pemanfaatannya sebagai hasil Invensi dan Inovasi nasional".

t. Pasal 35 ayat (2) UU-Sisnas Iptek: "Perlindungan atas Kekayaan Intelektual dan pemanfaatannya sebagaiman dimaksud pada ayat (1) dilaksanakan sesuai dengan ketentuan peraturan perundang-undangan.

u. Pasal 36 UU-Sisnas Iptek: "Pemerintah Pusat dan Pemerintah Daerah wajib menggunakan hasil Invensi dan Inovasi Nasional".

v. Pasal 37 UU-Sisnas Iptek: "Pemerintah Pusat wajib menjamin pemanfaatan hasil Penelitian, Pengembangan, Pengkajian dan Penerapan dalam bentuk Invensi dan Inovasi untuk pembangunan nasional”.

3. Peraturan Pemerintah Nomor. 20 Tahun 2005 tentang Alih Teknologi Kekayaan Intelektual Serta Hasil Kegiatan Penelitian dan Pengembangan oleh Perguruan Tinggi dan Lembaga Penelitian dan Pengembangan (PP-ALTEKI). Politik hukumnya terdapat dalam:

a. Pasal 2 PP-ALTEKI: "Perguruan tinggi dan lembaga litbang wajib mengusahakan alih teknologi kekayaan intelektual serta hasil kegiatan 
penelitian dan pengembangan yang dihasilkan melalui kegiatan penelitian dan pengembangan yang dibiayai sepenuhnya atau sebagian oleh Pemerintah dan/atau Pemerintah Daerah sejauh tidak bertentangan dengan ketertiban umum dan peraturan perundang-undangan".

b. Pasal 4 PP-ALTEKI: "Tujuan alih teknologi kekayaan intelektual serta hasil kegiatan penelitian dan pengembangan adalah: (a). menyebarluaskan ilmu pengetahuan dan teknologi (b). meningkatkan kemampuan rakyat dalam memanfaatkan dan menguasai ilmu pengetahuan dan teknologi guna kepentingan masyarakat dan negara".

c. Pasal 20 PP-ALTEKKI: "Alih teknologi kekakayaan intelektual serta hasil kegiatan penelitian dan pengembangan oleh perguruan tinggi dan lembaga litbang dilaksanakan melalui mekanisme: (a). lisensi (b). kerja sama (c). pelayanan jasa ilmu pengetahuan dan teknologi (d) publikasi".

4. Peraturan Presiden Nomor. 27 Tahun 2013 tentang Pengembangan Inkubator Wirausaha (Perpres-PIW), dengan petunjuk pelaksananya Peraturan Menteri Koperasi dan Usaha Kecil dan menengah Republik Indonesia Nomor. 24/Per/M.KUKM/IX/2015 tentang Norma, Standar, Prosedur dan Kriteria Penyelenggaraan Inkubator Wirausaha (Permenko-UKM NSPK-PIW), politik hukumnya terdapat dalam:

a. Pasal 1 ayat (1) Perpres-PIW: "Inkubator wirausaha adalah suatu lembaga intermediasi yang melakukan proses inkubasi terhadap peserta inkubasi (tenant)".

b. Pasal 1 ayat (2) Perpres-PIW: "Inkubasi adalah suatu proses pembinaan, pendampingan dan pengembangan yang diberikan Inkubator Wirausaha kepada peserta inkubasi (tenant)".

c. Pasal 2 Perpres-PIW: "Pengembangan Inkubator Wirausaha bertujuan untuk; (a). menciptakan dan mengembangkan usaha baru yang mempunyai nilai ekonomi dan berdaya saing tinggi (b). mengoptimalkan pemanfaatan sumber daya manusia terdidik dalam menggerakan perekonomian dengan memanfaatkan ilmu pengetahuan dan teknologi".

d. Pasal 3 Perpres-PIW: "Sasaran pengembangan incubator wirausaha adalah: (a). penumbuhan wirausaha baru dan penguatan kapasitas wirausaha pemula (startup) yang berdaya saing tinggi (b). penciptaan dan penumbuhan usaha baru yang mempunyai nilai ekonomi dan berdaya saing tinggi (c). Peningkatan nilai tambah pengelolaan potensi ekonomi melalui pemanfaatan ilmu pengetahuan dan teknologi (d). peningkatan aksebilitas wirausahawan atau calon wirausahawan untuk mengikuti program inkubasi. (e). peningkatan kemampuan dan keahlian pengelola incubator wirausaha untuk memperkuat kompetensi inkubator wirausaha (f). Pengembangan jejaring untuk memperkuat akses sumber daya manusia, kelembagaan, permodalan, pasar, informasi dan teknologi”. 
e. Pasal 4 Perpres-PIW: "Penyelenggaraan inkubator wirausaha dilakukan oleh Pemerintah, Pemerintah Daerah, Dunia Usaha, dan/atau masyarakat".

f. Pasal 8 Permenko-UKM NSPK-PIW: "Tahapan penyelenggaraan inkubator wirausaha terdiri dari: (a). Prainkubasi (b) Inkubasi (c) pasca inkubasi.

Penguatan Sistem Inovasi Nasional menjadi wahana utama dalam meningkatkan daya saing dan kohesi sosial demi mewujudkan masyarakat adil, makmur, sejahtera, mandiri dan beradab. Khusus Perguruan Tinggi memegang posisi dan peranan penting (Center of Ecellent) dalam menemukan inovasi, invensi dan produk yang dapt meningkatkan saya saing bangsa dan tentunya perkenomian bangsa (Lihat Gambar 3 berikut ini)

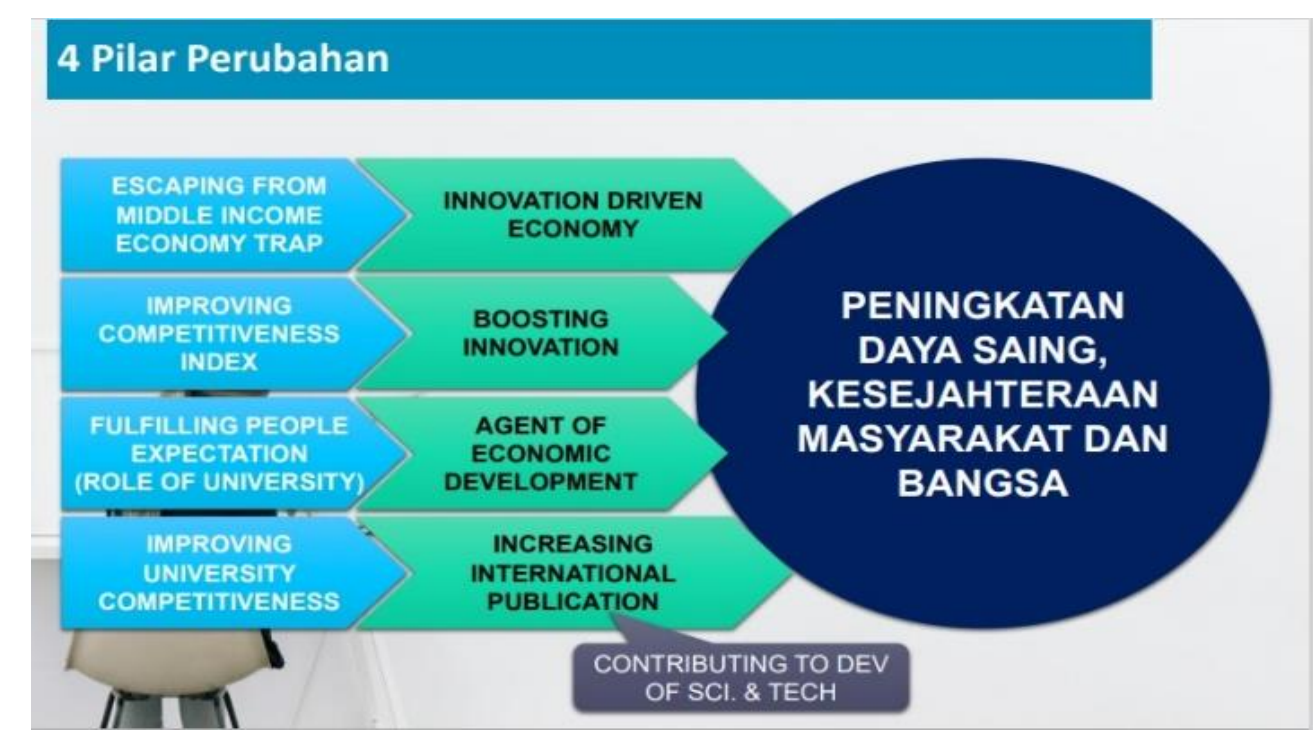

\section{Gambar 3 \\ Empat Pilar Perubahan Guna Peningkatan Daya Saing, Kesejahteraan dan Bangsa \\ Sumber: http://diskopukm.jatimprov.go.id/web-bo/file- content/76_238_kanwil\%20kumham.pptx}

Riset secara terminologi berasal dari bahasa Perancis "recherche" yang berarti "untuk mencari" merupakan turunan dari kata "recerchier" yaitu kata "re-" dan "cercier" yang bermakna "mencari". Kamus Besar Bahasa Indonesia (KBBI) memberikan pengertian riset sebagai "Penyelidikan (penelitian) suatu masalah secara bersistem, kritis, dan ilmiah untuk meningkatkan pengetahuan dan pengertian, mendapatkan fakta yang baru, atau melakukan penafsiran yang lebih baik.

Kerlinger memberikan definisi riset: "Scientific research is a systematic, controlled empirical and critical investigation of proposition about the presumed relationship about various phenomena". terjemahan: "Riset ilmiah adalah sistematik, terkontrol dan investigasi kritis terhadap dalil mengenai dugaan hubungan antar berbagai fenomena".

Definisi Penelitian dan Pengembangan dapat kita temui dalam Pasal 1 ayat (6) 
dan ayat (7) Undang-Undang Nomor 11 Tahun 2019 tentang Sistem Nasional Ilmu Pengetahuan dan Teknologi (UU-Sisnas Iptek).

Pasal 1 ayat (6) UU-Sisnas Iptek: "Penelitian adalah kegiatan yang dilakukan menurut metode ilmiah untuk memperoleh data dan informasi yang berkaitan dengan pemahaman tentang fenomena alam dan/atau sosial, pembuktian kebenaran atau ketidakbenaran suatu asumsi dan/ atau hipotesis, dan penarikan kesimpulan".

Pasal 1 ayat (7) UU-Sisnas Iptek: "Pengembangan adalah kegiatan untuk meningkatkan manfaat dan daya dukung Ilmu Pengetahuan dan Teknologi yang telah terbukti kebenaran dan keamanannya untuk meningkatkan fungsi dan manfaat Ilmu Pengetahuan dan Teknologi”.

Sebuah riset, penelitian dan pengembangan oleh Perguruan Tinggi agar bermanfaat bagi masyarakat dan industri melewati tahapan yang disebut dengan komersialisasi teknologi.

Secara umum komersialisasi teknologi bisa dimaknai sebagai "moving technology to a profitable position",(Nasution, Reza.A. Djuanda, Dadan, dan Rachmat, 2009) maksudnya suatu kondisi dimana teknologi yang telah dikembangkan bisa diaplikasikan kepada kegiatan produksi atau konsumsi dan mendatangkan keuntungan bagi penemunya.

Sebelum sampai tahapan komersialisasi tadi, ada fase intermediasi yakni hilirisasi dan inkubasi bisnis. Pertama, hilirisasi adalah implementasi hasil penelitian dalam berbagai hal (misal riset berorientasi pada manfaat seperti cara untuk mencegah banjir), sehingga masyarakat bisa menikmati hasilnya atau dengan bahasa lainnya yaitu proses mendekatkan hasil riset dan inovasi kepada penggunanya. Pengguna dalam hal ini adalah masyarakat bisa masyarakat pengguna umum, lembaga pemerintahan ataupun juga industri.(Astirin, 2018) Kedua, Pasal 33 ayat (1) Undang-Undang Nomor 11 Tahun 2019 tentang Sistem Nasional Ilmu Pengetahuan dan Teknologi memberikan definisi yang dimaksud "Inkubasi Teknologi" adalah proses pembinaan, pendampinganm dan pengembangan terhadap calon perusahaan pemula berbasis Teknologi oleh Inkubator Teknologi untuk memaksimalkan hasil Penelitian, Pengembangan, Pengkajian, dan Penerapan"

Penulis menggunakan Teori Sistem Hukum sebagai pisau analisa guna menjelaskan bahwa upaya mengkomersialisasikan hasil riset, peneltian dan pengembangan (kekayaan intelektual) oleh Perguruan Tinggi melalui kegiatan hirisasi dan inkubasi bisnis guna meningkatkan kemandirian dan daya saing bangsa, sudah dilaksanakan dengan menggu nakan 3 (tiga) komponen seperti yang di utarakan oleh Lawrence Friedman:

a. Legal Substansi: pengaturan hukum tentang penguasaan, penguatan, pengembangan, dan pemanfaatan ilmu dan teknologi hasil riset, penelitian dan pengembangan oleh Perguruan Tinggi diatur melalui dengan di undangkannya Undang-Undang Nomor 18 Tahun 2002 tentang Sistem Nasional Penelitian, Pengembangan, Penerapan Ilmu Pengetahuan dan Teknologi sebagaimana dirubah dengan Undang-Undang Nomor 11 Tahun 2019 tentang Sistem Nasional Ilmu 
Pengetahuan dan Teknologi, serta Peraturan Pemerintah Nomor 20 Tahun 2005 tentang Alih Teknologi Kekayaan Intelektual Serta Hasil Kegiatan Penelitian dan Pengembangan oleh Perguruan Tinggi dan Lembaga Peneltian dan Pengem bangan.

b. Legal Struktur: guna penanganan secara terpusat, terpadu dan terkoodinasi serta menyinergikan semua potensi riset baik yang terdapat di Perguruan Tinggi (P.T), Lembaga Penelitian dan Pengembangan di Kemen terian, BUMN, Perusahaan Swasta dan di masyarakat dibentuklah Badan Riset dan Inovasi Nasional (selanjutnya disingkat dan dikenal dengan istilah BRIN), melalui Peraturan Presiden Nomor 74 Tahun 2019 (Lembaran Negara Republik Indonesia Tahun 2019 Nomor 209).

Salah satu langkah penting dalam penguasaan sistem inovasi nasional yaitu penguatan kelembagaan Iptek. Hal ini agar lembaga Iptek dapat menghasilkan inovasi teknologi yang sesuai dengan kebutuhan masyarakat (pengguna). Perguruan Tinggi memegang peranan dalam meningkatkan kemampuan daya saing bangsa melalui riset, penelitian dan pengembangan sebagaiman konsep Tri Dharma Perguruan Tinggi. Pengorganisasian/Kelembagaan Manajemen Inovasi di Perguruan Tinggi diatur dalam Pasal 4, jo Pasal 6, jo Pasal 7 ayat (2), ayat (4) Peraturan Menteri Riset, Teknologi, dan Pendidikan Tinggi Nomor 24 Tahun 2019 tentang Manajemen Inovasi Perguruan Tinggi (Berita Negara Republik Indonesia Tahun 2019 Nomor 239)

Salah satu bentuknya yaitu Pusat Unggulan Ipteks Perguruan Tinggi (selanjutnya disingkat dan disebut dengan istilah PUI-PT). PUI-PT diharapkan menjadi sentral dari pengembangan Ipteks di Indonesia serta melibatkan seluruh pemangku kepentingan, Akademisi (Perguruan Tinggi), Pemerintah dan Dunia Industri.Pembahasan dalam artikel bertujuan untuk menjawab rumusan masalah dan pertanyaan-pertanyaan pene litian, menunjukkan bagaimana temuan-temuan itu diperoleh, menerangkan arti hasil penelitian, bagaimana hasil penelitian dapat memecahkan masalah serta kemungkinan pengembangannya. Pembahasan harus menjawab permasalahan dan tujuan penelitian.

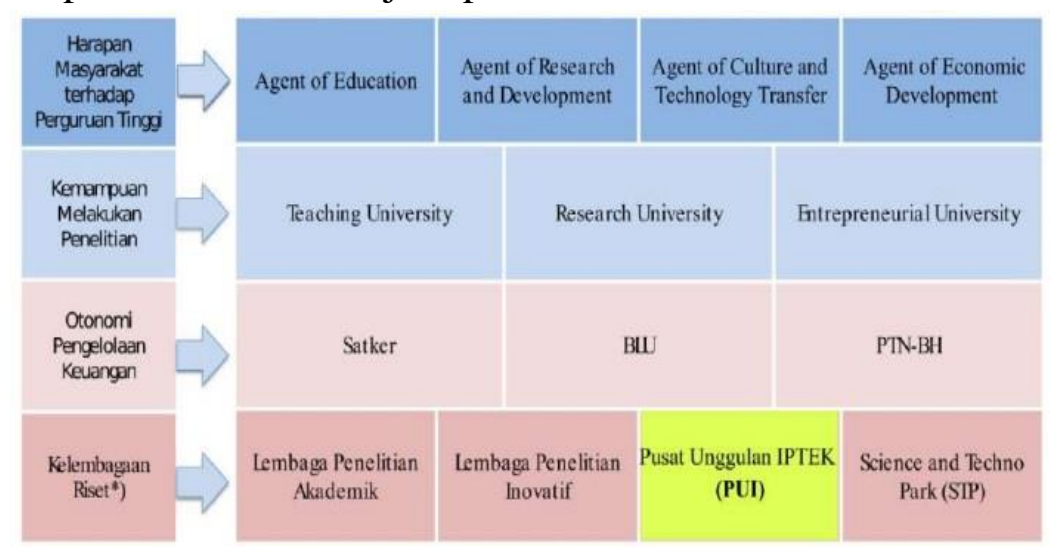

Gambar 4

Arah Pengembangan dan Tatakelola Perguruan Tinggi 
Sumber: Buku Panduan Pusat Unggulan Iptek Tahun 2020

c. Budaya Hukum: Indonesia sudah mempunyai aturan hukum tentang penelitian, alih teknologi kekayaan intelektual serta hasil penelitian dan pengembangan, pengembangan inkubator wirausaha, Manajemen Inovasi Perguruan Tinggi juga telah memiliki lembaga yang tugas pokonya menjalankan penelitian, pengembangan, pengkajian dan penerapan seta invensi dan inovasi terintegrasi yaitu Badan Riset Inovasi Nasional dibantu Forum Rektor Perguruan Tinggi Indonesia dan Kadin namu masih kerap terjadi di Indonesia hasil riset dan penelitian pengembangan oleh Perguruan Tinggi belum bisa dihilirisasi bahkan dikomersialisasikan

Penulis berdasarkan pemaparan diatas mencoba merumuskan politik hukum hilirisasi dan inkubasi bisnis hasil riset dan penelitian pengembangan perguruan tinggi, yakni:

a. sebagai bentuk jaminan perlindungan Hak Asasi Manusi sebagai konsekuensi bentuk negara Indonesia sebagai negara hukum sebagaimana dinyatakan Pasal 28C ayat (1) dan ayat (2) UUD 1945

b. sebagai bentuk politik hukum (legal policy) dari pemerintah yakni untuk menjadi sebuah negara mandiri dan berdaya saing melalui penguasaan teknologi

c. sebagai bentuk iuscontitutm (aturan hukum yang berlaku saat ini) dan pilihan cara yang dipilih pemerintah kedepan (ius costiendum) dalam menggubah aturan hukum yang ada

B. Konsep Ideal Sinegritas Elemen Quadruluple Helix Untuk Hilirisasi Dan Inkubasi Bisnis Hasil Riset Dan Penelitian Pengembangan Perguruan Tinggi

Kapasitas perguruan tinggi sebagai sumber inovasi teknologi (center of excellence) saat ini mengalami kendala dalam hal proses hilirisasi dan inkubasi bisnis hasil riset dan penelitian pengembangan yakni (Prasetyono, n.d.)

1. Pertama, tingkat kesiapan teknologi, kesiapan inovasi dan tingkat kesiapan manufaktur, tanpa ke-3 (tiga) kesiapan tersebut sebuah proses inovasi akan tersungkur kedalam lembah kematian inovasi (Valley of Death). Menteri Riset dan Teknologi/ Kepala Badan Riset dan Inovasi Indonesia, Bambang Brodjonegoro menyatakan banyak produk inovasi layu sebelum berkembang, karena tidak bisa melewati (valley of death), umumnya terjadi saat tahap dari purwarupa (prototype) produk menuju industrialisasi hingga komersialisasi

2. Kedua, ketersediaan dana anggaran, hasil studi bersama antara Akademi Ilmu Pengetahuan Indonesia (AIPI) dan Akademi Ilmuwan Muda Indonesia dengan judul "Membangun Pendanaan Penelitian yang Berkelanjutan dan Mandiri) menyimpulkan faktor pendanaan sangat penting untuk mewujudkan penelitian disamping infrastruktur penelitian dan kemampuan ilmiah yang mumpuni.

3. Ketiga, perlindungan dan kepemilikan Hak Kekayaan Intelektual (HKI) hasil riset dan penelitian pengembangan Perguruan Tinggi terkait sumber pendanaan. Dalam 
pembahasan diperkenankan mencantumkan subbab, pembabakan dalam bab pembahasan disesuaikan dengan permasalahan atau pertanyaan penelitian.

Istilah lembah kematian inovasi (valley of death) adalah istilah yang digunakan untuk menggambarkan kesenjangan (gap) antara pengembangan ilmu pengetahuan baru dan pengembangan komersial produk baru. Ekosismtem inovasi itu kompleks yakni jaringan interaksi antara para pelaku industri, pemerintah dan akademisi yang mendasari inovasi kegiatan dan kinerja di area tersebut. Ekosistem Inovasi ini terdiri dari 2 (dua) subsistem yaitu: Pertama, subsitem ekonomi penelitian (subsystems-research economy) yaitu merupakan produk penelitian akademik dan kerjasama industri dengan akademik, Kedua, subsistem ekonomi komersial (subsystem-commercial economy) yang mengubah hasil penelitian menjadi produk yang layak secara komersial. Lembah kematian (valley of death) ini muncul dari celah diantara 2 (dua) subsistem tadi dimana Investor (penyandang dana/pelaku industri) meng hentikan inisiatif inovasi dengan alasan kebutuhan yang tinggi untuk investasi dan hasil pasar (market) yang tidak pasti.(Jucevicius et al., 2016)

Dewasa ini dirasakan hasil riset dan penelitian pengembangan oleh Perguruan Tinggi masih kurang di pakai dunia Industri dan menjawab kebutuhan dan persoalan bangsa. Hal ini disebabkan antara lain masih terdapatnya ego masing-masing pihak yakni Academics (Perguruan Tinggi), Business (Dunia Industri), dan Goverment (Pemerintah) sehingga masing-masing berjalan sendiri-sendiri. Sebuah penelitian menghasilkan produk teknologi akan memiliki aspek pasar tinggi, bermanfaat dan laku di pasar apabila memliki tingkat kesiapan teknologi, kesiapan inovasi dan tingkat kesiapan manufaktur. Itu semua membutuhkan kerjasama semua pihak dalam siklus inovasi (Triple Helix) (seperti termuat dalam gambar 5).

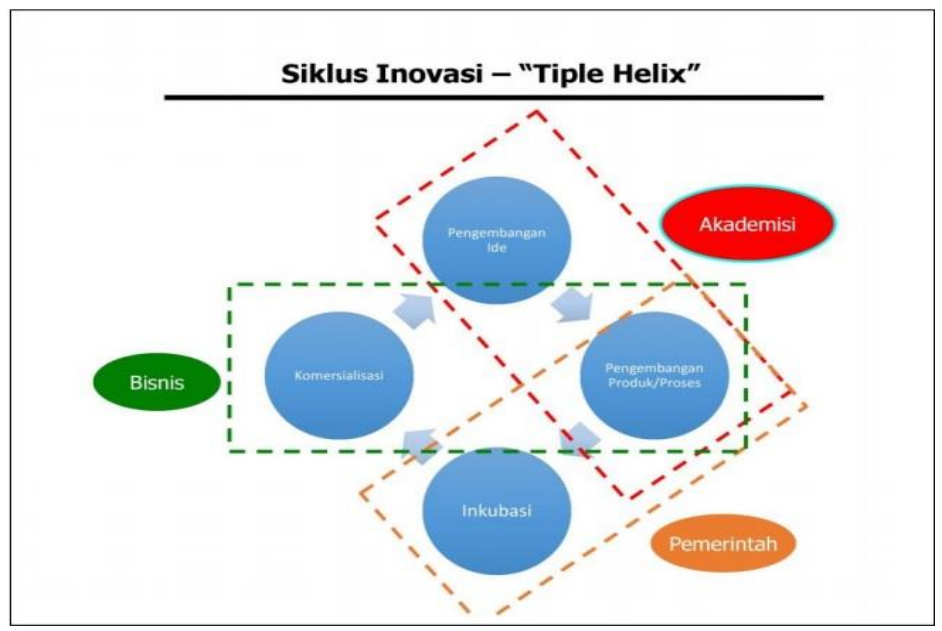

Gambar 5

Siklus Inovasi “Triple Helix" Peran dari Komponen Akademis, Pemerintah, dan dunia Usaha

Sumber: Ditjen Penguatan Riset dan Pengembangan 2015

Arif Satria berpendapat, agar inovasi Indonesia tumbuh subur, perlu dilakukan kolaborasi dengan industri, "strategi pengembangan inovasi dan kerjasama industri yang 
dapat dilakukan adalah" (Adit, 2020):

a. Adanya sinergi program kerjasama penelitian dan pengembangan. Kerjasamaitu dengan lembaga riset pemerintah, lembaga riset swasta, perguruan tinggi dan dunia usaha. Sebagai contoh di Jepang dimana inovasinya bersinergi dengan industri dalam satu kawasan.

b. Langkah kedua adalah implementasi teknologi baru melalui pilot plant.

c. Ketiga, adanya jaminan risiko dari pemerintah pada implementasi teknologi baru

Terdapat 3 (tiga) model Triple Helix:(Anggota Dewan Riset Nasional, 2020)

a. Konfigurasi statis: Pemerintah memainkan peran utama, mendorong akademisi dan industri, tetapi juga membatasi kapasitas mereka untuk memulai dan mengembangkan transformasi inovatif (seperti di Rusia, Tiongkok, serta beberapa negara Amerika Latin dan Eropa Timur).

b. Konfigurasi laissez-faire: Model ini ditandai dengan intervensi negara terbatas dalam ekonomi (seperti di Amerika Serikat dan beberapa negara Eropa Barat), dengan industri sebagai kekuatan pendorong dan dua bidang lain bertindak sebagai struktur pendukung tambahan dengan peran terbatas dalam inovasi-universitas yang bertindak terutama sebagai penyedia modal sumber daya manusia yang terampil dan pemerintah terutama sebagai pengatur mekanisme sosial dan ekonomi

c. Konfigurasi seimbang: Ini khusus untuk transisi ke masyarakat pengetahuan. Universitas dan lembaga pengetahuan lain bertindak dalam kemitraan dengan industri dan pemerintah, bahkan memimpin inisiatif bersama

Evolusi metafora triple helix dari hubungan universitas-industri-pemerintah diposisikan dapat dipelajari dalam konteks perubahan ekonomi global. Juga dapat untuk menyoroti bagaimana hubungan ini berlanjut dan bermutasi atau berubah. Dapat pula dicermati kondisi ketika triple helix mungkin terlihat terurai dalam menghadapi tekanan pada masing-masing dari tiga helix: universitas-industri-pemerintah.

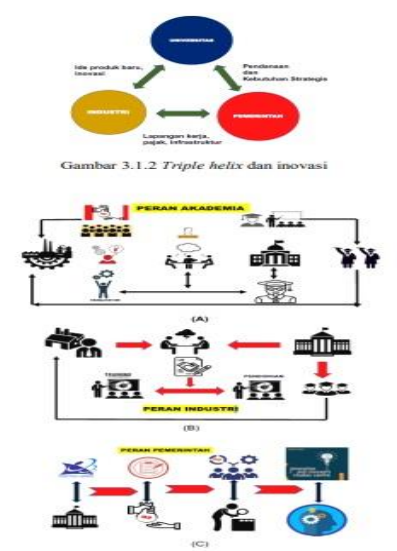

Gambar 6

Triple Helix

Sumber: Dewan Riset Nasional, Peran Strategis Inovasi Dalam Meningkatkan Pertumbuhan Ekonomi, 2020 
Dinamika timbal balik dari inovasi dan triple helix dalam ekonomi global telah menjadi bidang baru yang dieksplorasi secara sistemis, antara lain juga bagaimana hubungan itu memengaruhi penda patan nasional suatu negara, misalnya melalui pajak. Ketiga komponen triple helix dihubungkan oleh route atau kepentingan, yaitu inovasi dan ide produk baru antara universitas dan industri, pendanaan dan kebutuhan strategis antara universitas dan pemerintah, serta lapangan kerja, pajak, dan infrastruktur dalam hubungan pemerintah dan industri.

Dengan sangat cepat, konsepsi triple helix saat ini berkembang. Turunan dari triple helix menjadi quadruple helix dan lain-lain. Salah satu contoh quadruple helix memasukkan unsur media, civil society, dan/atau masalah lingkungan (lihat gambar 7)

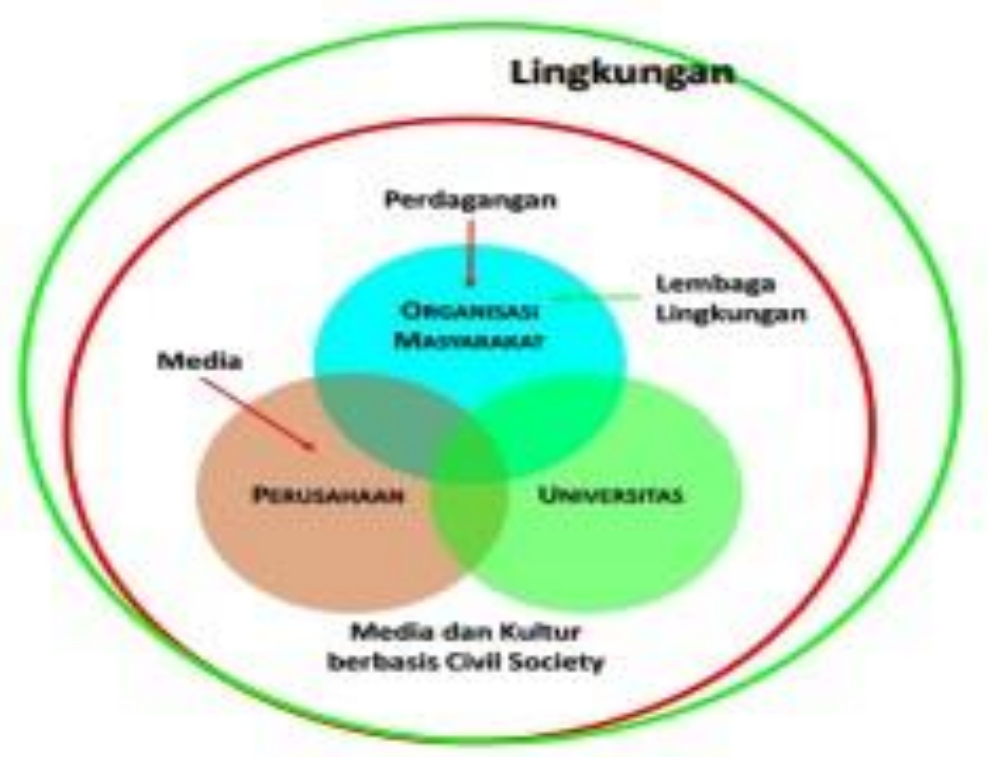

Gambar 7

Quadruple Helix

Sumber: Dewan Riset Nasional

\section{Kesimpulan}

Kesimpulan dari penelitian tersebut adalah politik hukum hilirisasi dan inkubasi bisnis hasil riset dan penelitian pengembangan perguruan tinggi, merupakan sebagai bentuk; jaminan perlindungan Hak Asasi Manusi sebagai konsekuensi bentuk negara Indonesia sebagai negara hukum sebagaimana dinyatakan Pasal 28C ayat (1) dan ayat (2) UUD 1945; juga merupakan bentuk politik hukum (legal policy) dari pemerintah yakni untuk menjadi sebuah negara mandiri dan berdaya saing melalui penguasaan teknologi; atau juga sebagai bentuk iuscontitutm (aturan hukum yang berlaku saat ini) dan pilihan cara yang dipilih pemerintah kedepan (ius costiendum) dalam menggubah aturan hukum yang ada. Quadruple Helix: merupakan perkembangan dari Triple Helix, sangat dibutuhkan dalam merumuskan hubungan yang sejajar antara helix yakni: pemerintah, perguruan tinggi, dan industri. 


\section{BIBLIOGRAFI}

Adit, A. (2020). Pentingnya Kolaborasi Inovasi Perguruan Tinggi Dengan Inddustri. Kompas. Google Scholar

Anggota Dewan Riset Nasional. (2020). Peran Strategis Inovasi Dalam Peningkatan Pertumbuhan Ekonomi (A. E. Hadi, Sudharto, Bambang, Setiadi, Sakya (Ed.); 2020th Ed.). Dewan Riset Nasional.

Asmara, C. G. (2020). Daya Saing Ri Melorot 8 Peringkat, Ri Kalah Cepat ? Cnbc Indonesia, 1-3. Google Scholar

Asnawi, A. (2018). Produktivitas Rakyat Dan Daya Saing Indonesia Di Pasar Internasional Sebagai Upaya Mendukung Tercapainya Pembangunan Nasional. Jurnal Ilmiah Administrasi Bisnis Dan Inovasi, 2(1). Google Scholar

Astirin, O. P. (2018). Hilirisasi Produk Riset Melalui Kegiatan Pengabdian Kepada Masyarakat *). Jurnal Sniemas, 1-5. Google Scholar

H.S, S. (2015). Penerapan Teori Hukum Pada Penelitian Disertasi Dan Tesis (E. S. Nurbani (Ed.); Buku Ii). Rajawali Pers. Google Scholar

Irawan, C. (2012). Politik Hukum Hak Kekayaan Intelektual Indonesia-Kritik Terhadap Wto/Trips Agreement Dan Uapaya Membangun Hukum Kekayaan Intelektual Demi Kepentingan Nasional (Cetakan Ke). Cv. Mandar Maju. Google Scholar

Jucevicius, G., Juceviciene, R., Gaidelys, V., \& Kalman, A. (2016). The Emerging Innovation Ecosystems And "Valley Of Death": Towards The Combination Of Entrepreneurial And Institutional Approaches. Engineering Economics, 27(4), 430-438. Https://Doi.Org/10.5755/J01.Ee.27.4.14403. Google Scholar

Kalalo, J. J. J. (2018). Politik Hukum Perlindungan Hak Ulayat Masyarakat Hukum Adat Di Daerah Perbatasan. In Makassar: Disertasi Universitas Hasanuddin. Universitas Hasanuddinmakasar. Google Scholar

Muabezi, Z. A. (2017). Negara Berdasarkan Hukum (Rechtsstaats) Bukan Kekuasaan (Machtsstaat). Jurnal Hukum Dan Peradilan, 6(3), 421. Https://Doi.Org/10.25216/Jhp.6.3.2017.421-446. Google Scholar

Nasution, Reza.A. Djuanda, Dadan, Dan Rachmat, R. (2009). Studi Literatur Tentang Komersialisasi Teknologi Di Perguruan Tinggi: Proses, Potensi, Model, Dan Aktor. Jurnal Manajemen Teknologi, 8(2). Google Scholar

Patamatta, J. D. (2020). Konsep Negara Hukum Di Indonesia Dalam Perspektif Piagam Madinah. Al Amin: Jurnal Kajian Ilmu Dan Budaya Islam, 3(1), 69-82. Google Scholar

Peraturan Presiden No 18 Tahun 2020 Tentang Rencana Pembangunan Jangka 
Muhammad Rizki Noveri, I Putu Eka Cakra, Joko Setiyono

Menengah Nasional Tahun 2020-2024. Google Scholar

Prasetyono, A. P. (N.D.). Valley Of Death Inovasi. Google Scholar

Rahardjo, S. (2009). Hukum Progresif Sebuah Sintesa Hukum Indonesia. Genta Publishing. Google Scholar

Rani, F. A. (2011). Konsep Negara Hukum Dan Kekuasaan Kehakiman Yang Merdeka. In S. D. Harijanti (Ed.), Negara Hukum Yang Berkeadilan Kumpulan Pemikiran Dalam Rangka Purnabakti Prof. Dr. H. Bagir Manan, S.H, M.Cl. (Pp. 579-605). Pskn-Htn Fh-Unpad.

Rusnan. (2014). Konsep Negara Hukum Dalam Hubungan Kekuasaan Freiss Ermerssen Dalam Welfare State. Ius-Kajian Hukum Dan Keadilan, Ii(4), 1-10. Google Scholar

Sekretariat Jenderal Mpr. (N.D.). Undang-Undang Dasar Negara Republik Indonesia Tahun 1945 Dalam Satu Naskah. 1-28. Google Scholar

Soebagyo, H. (2018). Peningkatan Peran Riset Iptek Dan Pendidikan Tinggi Untuk Abstrak Pendahuluan. Seminar Nasional Instrumentasi, Kontrol Dan Otomasi (Sniko), 10-11. Google Scholar

Suteki. (2015). Masa Depan Hukum Progresif (Buku I). Thafa Media. Google Scholar

Suteki. (2018). Metode Penelitian Hukum-Filsafat, Teori, Dan Praktik (G. Taufani (Ed.); Cetakan I). Rajawali Pers. Google Scholar

Wijaya, M. H. (2013). Keberadaan Konsep Rule By Law (Negara Berdasarkan Hukum) Dalam Teori Negara Hukum The Rule Of Law. Google Scholar

Zoelva, H. (2015). Prospek Negara Hukum Indonesia: Gagasan Dan Realita. Hasanuddin Law Review, 1(2), 178. Google Scholar

\section{Copyright holder:}

Muhammad Rizki Noveri, I Putu Eka Cakra, Joko Setiyono (2021)

First publication right:

Syntax Literate: Jurnal Ilmiah Indonesia

This article is licensed under:

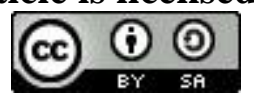

